\title{
Kefir Properties Prepared with Goat Milk and Black Rice (Oryza sativa $L$.) Extract and its Influence on the Improvement of Pancreatic $\beta$-Cells in Diabetic Rats
}

\author{
Nurliyani ${ }^{1 *}$, Ahmad Hamim Sadewa ${ }^{2}$, Sunarti ${ }^{2}$ \\ ${ }^{1}$ Department of Animal Product Technology, Faculty of Animal Science, Universitas Gadjah Mada, Yogyakarta, Indonesia; ${ }^{2}$ Department of \\ Biochemistry, Faculty of Medicine, Universitas Gadjah Mada, Yogyakarta, Indonesia
}

\section{A B S T R A C T}

This study were to evaluate the properties of kefir prepared with a combination of goat milk and black rice extract and its influence on the improvement of $\beta$-cells in streptozotocin-nicotinamide (STZ-NA) -induced diabetic rats. Kefir was divided into four groups using the following materials: goat milk (GM), goat milk + inulin $(G M+I N)$, goat milk + black rice extract (1:1)(GM + BRE), and goat milk + black rice extract + inulin $(G M+B R E+I N)$. After fermentation, all kefir were stored at $4{ }^{\circ} \mathrm{C}$ for 1 and $7 \mathrm{~d}$, and then were analyzed for microbial, chemical properties and antioxidant activity. Furthermore, three kinds doses of kefir combination from goat milk and black rice extract (GM + BRE) were administered to rats. Thirty male rats 8-12 weeks old were divided into 6 groups: 1) negative control (normal rats); 2) positive control (untreated diabetic rats); 3) diabetic rats fed kefir (1.0 ml); 4) diabetic rats fed kefir (2.0 ml); 5) diabetic rats fed kefir $(4.0 \mathrm{ml})$, and 6) diabetic rats received glibenclamide. After $28 \mathrm{~d}$ experiment, the rats were sacrificed for sampling pancreatic tissues. Subtitution of goat milk with black rice extract in kefir fermentation could decrease their $\mathrm{pH}$ and increase in radical-scavenging activity. Inulin addition able to increase $(p<0.05)$ in radical-scavenging activity of kefir. Alcohol and total phenolic contents of kefir increased $(\mathrm{p}<0.05)$ after $7 \mathrm{~d}$ of storage, while the $\mathrm{pH}$ decreased. To improve insulin-producing pancreatic $\beta$-cells in diabetic rats, it was required at least $2.0 \mathrm{ml}$ dose of kefir combination from goat milk and black rice extract to achieve similar effect to glibenclamide as antidiabetic agent.

Keywords: Kefir combination; Microbial properties; Chemical properties; Antioxidant; $\beta$-cells

\section{INTRODUCTION}

Kefir is fermented milk product as natural probiotics, has less acidic taste, yeasty aroma and foamed on stirred due to containing acid, alcohol and $\mathrm{CO}_{2}$ (Otles and Cagindi, 2003; Adriana and Socaciu, 2008). Raw material of kefir usually prepared from cow milk, but can also be prepared with other milk such as goat or sheep, coconut, rice and soy milk (Otles and Cagindi, 2003). According to Bergmann et al. (2010), the kinds of microorganism in kefir depend on origin of kefir grain that existing in polysaccharides matrix, where in the fermentation process will produce a variety of substances such amine, vitamins, acids, ethanol, and volatile compounds.

Kefir grains are added in kefir fermentation process which makes a difference in comparison to yoghurt fermentation. Diameter of kefir grains ranges from $0.3-3.5 \mathrm{~cm}$, and the grains consisted of $89-90 \%$ water, $0.2 \%$ lipids, $3 \%$ proteins, $6 \%$ sugars and $0.7 \%$ ashes (Bergmann et al., 2010). In addition, traditionally, yogurt has only one or two bacteria, whereas kefir tends to have several probiotic bacteria (Anandharaj et al., 2014). Various type of microorganism that present in kefir grains are lactic acid and acetic acid bacteria, yeasts and fungi (Witthuhn et al., 2005). Several organic acids resulted from fermentation by probiotics such as Lactobacillus kefiranofaciens, Candida kefir, Saccharomyces boluradii and resulted during storage can a role as an inhibitory substances which will affect their ability to survive (Shah, 2000; Sheela and Suganya, 2012). The mechanisms of inhibitory effect of these organic acids through the toxicity due to membrane cells damage, cytosol acidification and anion accumulation intracellularly (Pieterse et al., 2005). For their importance of physiological requirements, the lactic acid bacteria $(\mathrm{LAB})$ has regulatory activity which maintain their $\mathrm{pH}$ in cytoplasms and inracellular (Hutkins and Nannen, 1993).

\footnotetext{
*Corresponding author:

Nurliyani, Faculty of Animal Science, Universitas Gadjah Mada, JI. Fauna 3 Kampus UGM, Bulaksumur Yogyakarta 55281, Indonesia. E-mail: nurliyani@yahoo.com
} 
Prebiotics are non-digestible carbohydrate that resist to enzymatic degradation in saliva and small intestinal, so that it can be used as a substrat and stimulate a specific bacteria in the host colon (Kelly, 2008). Inulin-type prebiotics are linear fructans, have a minimum two and maximum 60 fructose units with beta $(2-1)$ fructosyl-fructose glycosidic, starting with glucose or no glucose unit, or with low or higher glucose proportion (Kelly, 2008; Sheela and Suganya, 2012). Inulin can be hydrolyzed by some strains of yeast that have inulinase activity, as determined previously by Cruz-Guerrero et al. (2006), that two strains Kluyveromyces marxianus and also one strain of $K$. lactis var. lactis showed very good inulinase producers. Information of inulin addition in fermented milk as an antioxidant and the changes in its antioxidant during storage is still limited.

Phenolic compounds (phenolic acids, flavonoids, anthocyanins and proanthocyanidins), tocopherols and tocotrienols (vitamin E), $\gamma$-oryzanol, and phytic acid are antioxidant components in rice (Goufo and Trindade, 2014). The antioxidant phenolic that present in plants have benefecial effects on clotting of blood and tumorogenesis (Kris-Etherton et al., 2002).

Goat milk is rich in various physiologically functional components, including proteins, vitamins (such as vitamins $\mathrm{E}$ and $\mathrm{C}$ ), flavonoids, and carotenoids with antioxidant properties. The antioxidant activity of goat milk is significantly affected by pasteurization treatment, milk lactation stages, type of feeding and geographic location (Alyaqoubi et al., 2014).

Lifestyle changes including dietary habit can cause the various degenerative diseases such as diabetes mellitus (DM), which tend to increase from year to year. Various antidiabetic drugs have been widely used for a long time such as glibenclamide having a hypoglycemic effect. The treatment of DM may not utilize antidiabetic drugs, as has been observed previously that use plant/herbal components and utilize animal products such as fermented milk. The profile of $\beta$-cells on the islets of Langerhans pancreatic tissue of diabetic rats treated with virgin coconut oil (VCO), and Nigella sativa L. (an annual herbaceous plant) has been studied by Uray (2009) and Kanter et al. (2004), respectively. While, the effect of fermented water kefir product on glycemic status and antioxidative properties of STZ- induced hyperglycemia has been studied by Judiono et al. (2011).

The purpose of this study was to evaluate the properties of goat milk kefir by $50 \%$ substitution with black rice extract, and its influence on the improvement of $\beta$-cells in pancreatic tissue of STZ-NA induced diabetic rats.

\section{MATERIALS AND METHODS}

\section{Black rice extract and kefir preparation}

Local black rice and milk of Ettawah Crossedbred goat were taken from Yogyakarta, Indonesia. Commercial inulin was provided by Sari Husada Milk Industry, whereas kefir grains was obtained from Center for Livestock Training (Malang-East Java, Indonesia). Local black rice (Yogyakarta, Indonesia) $500 \mathrm{~g}$ was left in $1 \mathrm{~L}$ of distillated water for $24 \mathrm{~h}$, then it was blended, and filtered with cotton sheet (Sirirat and Jelena, 2010). Kefir were prepared from 1) goat milk (GM); 2) goat milk + inulin $(\mathrm{GM}+\mathrm{IN}) ; 3)$ goat milk and black rice extract (1:1) (GM+BRE); and 4) goat milk+black rice extract $(1: 1)+$ inulin $(\mathrm{GM}+\mathrm{BRE}+\mathrm{IN})$. Inulin were added in GM+IN and GM+BRE+IN as much as $0.5 \mathrm{~g} / 100 \mathrm{ml}$.

Preparation of kefir according to Chen et al. (2006) with slight modifications. Raw goat milk and black rice extract were pasteurized at $90^{\circ} \mathrm{C}$ for $30 \mathrm{~min}$ in a water bath, and cooled to inoculation temperature. The heat-treated milk was inoculated with 3\% kefir grains and incubated at room temperature for $18 \mathrm{~h}$. After separating the grains and stirring, kefir samples were storage in refrigerator at $4^{\circ} \mathrm{C}$ for 1 and $7 \mathrm{~d}$, and then analyzed of microbial, titratable acidity, $\mathrm{pH}$, alcohol, total solid, total phenolic content and antioxidant activity. All experiments were repeated three times.

\section{Microbial analysis}

Samples of kefir $(1.0 \mathrm{ml})$ were diluted in $9 \mathrm{ml}$ physiological $\mathrm{NaCl}$, and the procedure were continued to obtain a final dilution of $10^{-6}$. About $0.1 \mathrm{ml}$ of $10^{-5}$ and $10^{-6}$ dilutions (appropriate decimal dilutions) were spread into each a sterile Petri dish on each medium. This was subjected to incubation at $37^{\circ} \mathrm{C}$ for $24 \mathrm{~h}$ for total counts, and $48 \mathrm{~h}$ for $\mathrm{LAB}$ and yeast. To determine the total counts, LAB and yeast populations, the colonies formed were counted and expressed in $\log \mathrm{CFU} / \mathrm{ml}$ (Rostita et al., 2011). Plate count agar (PCA) (Merck) medium was used for determination of total counts (Chen et al., 1983). Lactic acid bacteria were determined on modified deMan, Rogosa and Sharpe (MRS)

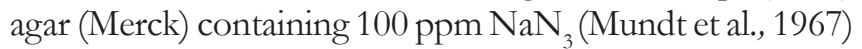
and $100 \mathrm{ppm} \mathrm{CaCO}_{3}$ (Hwanhlem et al., 2011). Malt extract agar (MEA)(Oxoid) containing 100 ppm chloramphenicol was used for determination of yeasts (Eissa et al., 2011).

\section{Titratable acidity analysis and measuring of $\mathrm{pH}$}

The $\mathrm{pH}$ of kefir was measured using a $\mathrm{pH}$-meter (HANNAHI 98103), and acidity was analyzed by titratable acidity according to Hashim et al. (2009) with slight modification. Titratable acidity is expressed as percentage of lactic acid, and determined by titrating $9 \mathrm{~g}$ of kefir with $0.1 \mathrm{~N} \mathrm{NaOH}$ using phenolphthalein as an indicator to an end-point of faint pink color. 


\section{Analysis of alcohol}

Alcohol in kefir samples were analyzed by Conway microdiffusion method (MacLeod, 1949) with modifications. This method using ethanol standard curve, saturated solution of potassium carbonate, saturated solution of potassium bichromate sulfuric acid. Absorbace of the sample was measured at $480 \mathrm{~nm}$ using a Spectrophotometer (Spectronic 200, Thermo Scientific).

\section{Analysis of total solid}

Total solid was calculated from moisture content. Samples were dried at $105^{\circ} \mathrm{C}$ for $24 \mathrm{~h}$ and the water content of the samples were gravimetrically determined (AOAC, 1995). Total solid $=100 \%$ - moisture content .

\section{Determination of total phenolic content and scavenging upon DPPH radicals}

The content of total phenolics was analyzed spectrophotometrically using the Folin Ciocalteu colorimetric method with standard curve of gallic acid (Chu et al. 2002).

The effect of kefir upon 2,2-Diphenyl-1-picrylhydrazyl (DPPH) radicals was estimated according to Liu et al. (2005a), by dilution sample with methanol and addition of DPPH. The capability of the test material to scavenge DPPH radicals was calculated as $(\%)=[1$ - (absorbance of the sample at $517 \mathrm{~nm}) /$ (absorbance of the control at $517 \mathrm{~nm}] \times 100$.

\section{Animal experimental}

Thirty male Wistar rats 8-12 weeks old were aclimated for 1 week with standard diet AIN-93 M (Reeves et al., 1993). The rats were divided into 6 groups of treatment $(n=5): 1)$ negative control (received standard diet only), 2) positive control (untreated diabetic rats), 3) diabetic rats + kefir (1.0 ml/200 g body weight), 4) diabetic rats + kefir (2.0 ml $/ 200 \mathrm{~g}$ body weight), 5) diabetic rats + kefir $(4.0 \mathrm{ml} / 200 \mathrm{~g}$ bodyweight), and 6) diabetic rats + glibenclamide $(50 \mathrm{mg} / \mathrm{kg}$ body weight). Kefir prepared from goat milk and black rice extract (1:1). In negative control rats were given $2.0 \mathrm{ml}$ of phosphate-buffered saline (PBS). Kefir and PBS were given orally with force feeding. Diabetic condition in rats by using induction with streptozotocin (STZ) $60 \mathrm{mg} / \mathrm{kg}$ and nicotinamide (NA) $120 \mathrm{mg} / \mathrm{kg}$, i.p (prepared in fresh solution in $0.1 \mathrm{M}$-citrate buffer, $\mathrm{pH}$ 6.3) at 0 day experiment (Akbarzadeh et al., 2007). After the rats became diabetic (3-5 d from induction) with fasting glucose level $>126 \mathrm{mg} / \mathrm{dL}$, the rats begin to be treated. After $28 \mathrm{~d}$ (at the end of treatment), the rats were sacrificed by being given ketamine $(80 \mathrm{mg} / \mathrm{kg})$ anesthesia, and the pancreatic islets were sampled for immunohistochemical analysis. All procedures related to animal experiment in this study was approved by Medical and Health Research Ethics Committee (MHREC),
Faculty of Medicine Universitas Gadjah Mada, Indonesia (Approval number: KE/FK/560/EC).

\section{Immunohistochemical analysis}

Slides were deparaffinised with xylene and hydrated with ethanol. Slides were immersed into glass jar containing $0.3 \% \mathrm{H}_{2} \mathrm{O}_{2}$ in methanol solution. $\mathrm{H}_{2} \mathrm{O}_{2}$ was removed and washed with aquadest three times, and then washed with phosphate-buffered saline (PBS) three times. Slides were placed into humid chamber, and incubated with background sniper solution for $10 \mathrm{~min}$. This background sniper was removed and then incubated with mouse monoclonal insulin primary antibody (dilution 1:1000) (abcam, [K36aC10] ab6995, Cambridge, USA) for $30 \mathrm{~min}$. Antibody was removed and washed the slides with PBS three times. The slides were incubated with secondary antibody in humid chamber for $10 \mathrm{~min}$, and then washed with PBS three times. Slides were placed into humid chamber for incubate with streptavidin-horseradishperoxidase (HRP) for $10 \mathrm{~min}$. Slides were washed with PBS three times and then incubated with 3,3'-diaminobenzidine (DAB) substrate (dilution 1:50) for 15 min in dark humid chamber. Slides were washed with aquadest five times, and then counterstained with haematoxylin and mounted with coverslips and examined under the light microscope. The number of Langerhans islet and insulin-positive cells were calculated using colony counter, and then documented by Opti Lab (SOP No A-007) microscope.

\section{Statistical analysis}

The data on microbial, chemical and antioxidant of kefir were expressed as mean \pm standard deviation, and comparison between treatment were analyzed by twoway ANOVA followed by Duncan's Multiple RangeTest (DMRT). The number of Langerhans and $\beta$ - cells were analyzed by one-way ANOVA, and DMRT for comparison between treatment. Statistical analysis were performed using the program Statistical Package For Social Sciences (SPSS), version 12.0 (SPSS, 2003).

\section{RESULTS AND DISCUSSION}

\section{Microbial properties}

The average of total count, LAB and yeast of kefir made from GM, GM+IN, GM+BRE and GM+BRE+IN that stored for 1 and $7 \mathrm{~d}$ at $4^{\circ} \mathrm{C}$ were not significantly different. This means indicate that addition of inulin or subtitution with $50 \%$ of black rice extract into goat milk had no effect on microbial quality of kefir (Table 1).

During $7 \mathrm{~d}$ of storage, inulin or components in black rice extract had no effect on microbial in kefir. This may be due to low microbial activity in kefir during cold storage. Thus, 
Nurliyani, et al.: Kefir effect on diabetis

Table 1: The average of total count, LAB and yeast (log CFU/ml) of kefir groups stored at $4^{\circ} \mathrm{C}$ for 1 and 7 day

\begin{tabular}{|c|c|c|c|c|c|c|}
\hline \multirow{2}{*}{$\begin{array}{l}\text { Kefir } \\
\text { groups }\end{array}$} & \multicolumn{2}{|c|}{ Total count ${ }^{\text {ns }}$} & \multicolumn{2}{|c|}{ Total LAB ${ }^{\text {ns }}$} & \multicolumn{2}{|c|}{ Total yeast $^{\text {ns }}$} \\
\hline & $1 \mathrm{~d}$ & $7 d$ & $1 \mathrm{~d}$ & $7 d$ & $1 \mathrm{~d}$ & $7 d$ \\
\hline$\overline{\mathrm{GM}}$ & $8.97 \pm 0.19$ & $8.85 \pm 0.10$ & $8.22 \pm 0.67$ & $8.01 \pm 0.53$ & $8.01 \pm 0.53$ & $8.20 \pm 0.05$ \\
\hline $\mathrm{GM}+\mathrm{IN}$ & $9.38 \pm 0.45$ & $8.88 \pm 0.19$ & $7.55 \pm 0.22$ & $7.68 \pm 0.30$ & $7.68 \pm 0.30$ & $8.33 \pm 0.06$ \\
\hline GM+BRE & $8.89 \pm 0.10$ & $8.96 \pm 0.39$ & $8.42 \pm 0.39$ & $7.95 \pm 0.48$ & $7.95 \pm 0.48$ & $8.41 \pm 0.45$ \\
\hline GM+BRE+IN & $9.06 \pm 0.28$ & $9.21 \pm 0.48$ & $8.79 \pm 0.40$ & $8.14 \pm 0.43$ & $8.14 \pm 0.43$ & $7.92 \pm 0.46$ \\
\hline Average $^{\text {ns }}$ & $9.07 \pm 0.31$ & $8.97 \pm 0.31$ & $8.2467 \pm 0.60$ & $7.9483 \pm 0.41$ & $7.94 \pm 0.41$ & $8.21 \pm 0.34$ \\
\hline
\end{tabular}

ns: Not significant

there was no hydrolyzed inulin or degraded components of black rice extract in a short period of cold storage. The result of this study was similar to a previous study, that $2 \%$ inulin did not increase kefir grain biomass after $30 \mathrm{~d}$ at $25^{\circ} \mathrm{C}$ (Guzel-Seydim et al., 2011), or after $1 \mathrm{~d}$ storage at $4^{\circ} \mathrm{C}$ (Montanuci et al., 2012). However, after $28 \mathrm{~d}$ storage resulted in the reduction by $1 \log$ in the viability of LAB (Montanuci et al., 2012) due to decrease in $\mathrm{pH}$ during storage.

In a previous study, showed that during storage of cheese which enrich with inulin $(2.5 \mathrm{~g} / 100 \mathrm{~g}$ cheese) has more number probiotic $L$. plantarum compared to cheese without inulin (Modzelewska-Kapitula et al., 2007). Similarly, when Lactobacillus rhamnosus growth together with Streptococcus thermophilus and all metabolites products were enhanced by inulin addition $4 \mathrm{~g} / 100 \mathrm{ml}$ milk. The cell biomass and metabolites were stimulated by the releasing fructose from inulin hydrolyzed for energy source in metabolism (Oliveira et al., 2012). However, inulin can not be hydrolyzed in cold storage with a short period of time, but inulin will undergo hydrolysis when stored in acidic conditions in a long periode of time. According to Montanuci et al. (2012), at the end of storage period (day 28), the inulin content was reduced by an average of $8 \%-9 \%$. Since grain-fermented kefirs were more acidic during storage, the partial hydrolysis of inulin added $1.5 \mathrm{~g} / 100 \mathrm{ml}$ in milk formulations was more pronounced.

Differences of results in this study in comparison to results from a previous study is probably related to the effect of inulin on the total microbial number mentioned above, which may be due to differences in the use of probiotics and inulin dose. Kefir contains more a total microbial count because it consists of a wide variety of bacteria and yeast, so inulin seems to have no influence on the microbial growth. This was similar to previous studies, although the inulin dose used was greater $(2 \%)$ than this study $(0.5 \%)$ also showed no differences in biomass of kefir. However, if the probiotics was used only one type, so that inulin provided a significant effect on the growth of probiotics. It was also possible to increase the growth of probiotics in kefir required inulin in higher doses.

Black rice extract used for the substitution of $50 \%$ goat's milk in the production of kefir in this study, did not decrease the number of total count, $\mathrm{LAB}$ and yeast. This indicates that nutritional components in black rice extract can be used by microorganism in kefir grains. Lactic acid bacteria also able to ferment rice media because it is supported by carbohydrates, vitamins and protein present in germinated brown rice and brown rice (Trachoo et al., 2006).

\section{Chemical properties}

Table 2 showed that goat milk kefir (GM) and goat milk kefir with inulin $(G M+I N)$ have a higher acidity $(p<0.05)$ than goat milk kefir with black rice kefir (GM+BRE) and goat milk added with black rice extract and inulin $(\mathrm{GM}+\mathrm{BRE}+\mathrm{IN})$. However, kefir containing black rice extract have higher $\mathrm{pH}(\mathrm{p}<0.01)$ than kefir without black rice extract. Inulin which was added in kefir has no effect on acidity and $\mathrm{pH}$. Storage time had no effect on kefir acidity, but the effect on kefir $\mathrm{pH}(\mathrm{p}<0.01)$.

Kefir from 100\% goat milk contains lactose which was higher than kefir containing $50 \%$ goat milk, thus the acidity (as lactic acid) of 100\% goat milk kefir was higher than 50\% goat milk kefir. However, the high acidity of $100 \%$ goat milk kefir (GM and GM+IN) was not accompanied with a lower $\mathrm{pH}$. Actually, the lower $\mathrm{pH}$ values found in kefir from $\mathrm{GM}+\mathrm{BRE}$ or $\mathrm{GM}+\mathrm{BRE}+\mathrm{IN}$ which containing $50 \%$ black rice extract. This was because black rice extract containing carbohydrate compounds that can be metabolized by microbes in the kefir grains that produce organic acids that contributes to decrease in $\mathrm{pH}$ value. In addition, kefir fermentation also produces acetic acid by acetic acid bacteria. Acetic and lactic acid that produced during kefir fermentation process have inhibitory effect through the undissociated form of these acids (Garrote et al., 2000).

The $\mathrm{pH}$ of kefir made from goat milk (4.73-4.75) and kefir containing black rice extract in this study (4.01-4.07) were different with the previous study that rice milk kefir has higher $\mathrm{pH}$ (4.41) than cow milk kefir (4.26) (Sirirat and Jelena, 2010). This differences due to different in raw materials of kefir. In this study kefir made from goat milk and black rice extract (1:1), whereas that kefir according to Sirirat and Jelena (2010) made from cow milk and kefir from rice milk only.

Kefir stored at $4^{\circ} \mathrm{C}$ for $7 \mathrm{~d}$ has lower $\mathrm{pH}$ than kefir stored for $1 \mathrm{~d}$. This indicates that there was a degradation of 
Table 2: The average of acidity and $\mathrm{pH}$ of kefir groups stored at $4^{\circ} \mathrm{C}$ for 1 and 7 day

\begin{tabular}{|c|c|c|c|c|c|c|}
\hline \multirow[t]{2}{*}{ Kefir groups } & \multicolumn{3}{|c|}{ Acidity (\%) } & \multicolumn{3}{|c|}{$\mathrm{pH}$} \\
\hline & $1 \mathrm{~d}$ & $7 \mathrm{~d}$ & Average & $1 \mathrm{~d}$ & $7 d$ & Average \\
\hline$\overline{\mathrm{GM}}$ & $0.87 \pm 0.20$ & $0.99 \pm 0.10$ & $0.93 \pm 0.15^{a}$ & $4.82 \pm 0.10$ & $4.68 \pm 0.13$ & $4.75 \pm 0.13^{a}$ \\
\hline GM+IN & $0.82 \pm 0.13$ & $1.01 \pm 0.15$ & $0.92 \pm 0.16^{a}$ & $4.86 \pm 0.06$ & $4.61 \pm 0.13$ & $4.73 \pm 0.16^{a}$ \\
\hline GM+BRE & $0.64 \pm 0.08$ & $0.67 \pm 0.16$ & $0.66 \pm 0.11^{b}$ & $4.20 \pm 0.12$ & $3.93 \pm 0.13$ & $4.07 \pm 0.18^{b}$ \\
\hline $\mathrm{GM}+\mathrm{BRE}+\mathrm{IN}$ & $0.63 \pm 0.11$ & $0.68 \pm 0.16$ & $0.65 \pm 0.12^{b}$ & $4.13 \pm 0.12$ & $3.89 \pm 0.12$ & $4.01 \pm 0.17^{b}$ \\
\hline Average & $0.74 \pm 0.16^{p}$ & $0.84 \pm 0.21^{p}$ & $0.79 \pm 0.19$ & $4.50 \pm 0.36^{p}$ & $4.28 \pm 0.39^{9}$ & $4.39 \pm 0.39$ \\
\hline
\end{tabular}

Different letters $(a, b)$ in the same column or the same row $(p, q)$ indicate significant difference for acidity $(p<0.05)$ and $p H(p<0.01)$

Table 3: The average of alcohol and total solid of kefir groups stored at $4^{\circ} \mathrm{C}$ for 1 and 7 day

\begin{tabular}{|c|c|c|c|c|c|c|}
\hline \multirow{2}{*}{$\begin{array}{l}\text { Kefir } \\
\text { groups }\end{array}$} & \multicolumn{3}{|c|}{ Alcohol (\%) } & \multicolumn{3}{|c|}{ Total solid (\%) } \\
\hline & $1 \mathrm{~d}$ & $7 d$ & Average & $1 \mathrm{~d}$ & $7 d$ & Average \\
\hline$\overline{\mathrm{GM}}$ & $0.24 \pm 0.16$ & $0.36 \pm 0.13$ & $0.30 \pm 0.14^{a}$ & $12.26 \pm 1.89$ & $13.60 \pm 2.25$ & $12.93 \pm 2.00^{a}$ \\
\hline $\mathrm{GM}+\mathrm{IN}$ & $0.28 \pm 0.13$ & $0.44 \pm 0.07$ & $0.36 \pm 0.13^{a}$ & $12.80 \pm 0.81$ & $12.54 \pm 1.90$ & $12.67 \pm 1.30^{\circ}$ \\
\hline GM+BRE & $0.27 \pm 0.11$ & $0.39 \pm 0.07$ & $0.33 \pm 0.10^{a}$ & $7.09 \pm 1.45$ & $6.22 \pm 0.59$ & $6.65 \pm 1.09^{b}$ \\
\hline GM+BRE+IN & $0.29 \pm 0.12$ & $0.34 \pm 0.13$ & $0.31 \pm 0.12^{a}$ & $6.73 \pm 0.99$ & $6.78 \pm 0.96$ & $6.75 \pm 0.87^{b}$ \\
\hline Average & $0.27 \pm 0.11^{p}$ & $0.38 \pm 0.10^{q}$ & $0.32 \pm 0.12$ & $9.72 \pm 3.16^{p}$ & $9.78 \pm 3.71^{p}$ & $9.75 \pm 3.37$ \\
\hline
\end{tabular}

Different letters $(a, b)$ in the same column or the same row $(p, q)$ indicate significant difference for alcohol $(p<0.05)$ and total solid $(p<0.01)$

kefir components into lactic acid and other organic acids during storage, resulting in a significant decrease in $\mathrm{pH}$ value. During fermentation lactose will be hydrolyzed into lactic acid and aroma substances. Other than lactic acid, a thermophilic bacteria is also produce acetaldehyde, while some mesophilic bacteria will produce diacetyl and able to use citrate (Adriana and Socaciu, 2008).

In this study, kefir acidity only express the lactic acid percentage, whereas that determines the $\mathrm{pH}$ value is not only the lactic acid, but also the accumulation of several other organic acids produced during fermentation and storage of kefir. Because of storage is done at low temperatures, the growth of lactic acid bacteria is inhibited, so that did not occur a significant increase in lactic acid during storage (Table 2). According to Leite et al. (2013), during fermentation and $7 \mathrm{~d}$ of storage at $4^{\circ} \mathrm{C}$, the content of lactose, citrate and $\mathrm{pH}$ of kefir reduced and enhanced in the concentration of other organic acid such as lactic, acetic, butyric and propionic acids besides glucose and galactose.

The average of alcohol in all groups of kefir were not significantly different, whereas the alcohol content of kefir stored for $7 \mathrm{~d}$ was higher than stored $1 \mathrm{~d}$ (Table 3). Since the total number of yeast in all groups of kefir were not significantly different (Table 1), so there were no differences in alcohol content. Inulin which was added to the kefir had no effect on alcohol production.

During fermentation, lactic acid bacteria convert lactose to lactic acid and other flavor compounds, and lactosefermenting yeasts produce $\mathrm{CO}_{2}$ and small amounts of ethanol (Fakruddin et al., 2013). Kefir is a fermented milk baverages resulted from the activity of microorganism in kefir grain consisting of $\mathrm{LAB}$ and yeasts that ferment and non- ferment lactose. Usually, the yeasts can metabolize glucose and galactose (Adriana and Socaciu, 2008).

The alcohol content of kefir stored for $7 \mathrm{~d}$ was higher than stored $1 \mathrm{~d}$. This result similar to a previous study by Leite et al. (2013), from $18 \mathrm{~h}$ fermentation to $7 \mathrm{~d}$ of storage at $4^{\circ} \mathrm{C}$, the concentration of ethanol in kefir increased significantly. Results of other study conducted by Oner et al. (2010) showed that ethanol production from kefir is not affected by the milk type, but more influenced by kefir microflora, and change the quantity of ethanol depends on the length of storage time and the culture type.

Total solid of kefir containing black rice extract $(\mathrm{GM}+\mathrm{BRE}$ and $\mathrm{GM}+\mathrm{BRE}+\mathrm{IN})$ was lower $(\mathrm{p}<0.01)$ than kefir made from goat milk (GM and GM+IN), whereas storage time had no effect on total solid of kefir (Table 3). Inulin which was added in kefir had no effect on kefir total solid. This means that total solid was more influenced by raw material of kefir. The total solid contents of goat milk ranging from $12.67-12.93 \%$ (Table 3), and moisture content of black rice ranges from 11.26-12.59\% (Sompong et al., 2011). Since black rice diluted with water for making extract (1:2), so that the moisture content of kefir made from goat's milk and black rice extract (1:1)(GM+BRE) was higher than kefir made from 100\% goat milk (GM). Thus, their solid content of GM+BRE was lower than GM kefir.

\section{Antioxidant activity}

The antioxidant activity, as expressed through the total phenolic content (TPC) of all groups of kefir were not significantly different. Substitution of goat milk with black rice extract or addition of inulin in goat milk kefir showed an increase in the average of total phenolic 
content, but this increase was not significantly different. This mean indicates that subtitution of black rice extract and addition of inulin had no effect on total phenolic contents of goat milk kefir. However, the total phenolic of kefir stored for $7 \mathrm{~d}$ was higher $(\mathrm{p}<0.05)$ than kefir stored for 1d (Table 4). This may be due to degradation of kefir components by microorganism produce phenolic compounds during storage. Similarly with a previous study that soybean-cow milk yoghurt showed highest value of total phenolic content on day 21 of storage in refrigerator (Shori, 2013). This means during cold storage of fermented milk was still occur degradation by starter which produces phenolic compound. In this respect, it is known that phenolic or polyphenol has an aromatic ring one or more phenol hydroxyl substituents (Lattanzio et al., 2006). The existing of aromatic amino acids in the peptide fractions caused by proteinase and peptidase activity in the proteolytic system of lactic acid bacteria are released and accumulated during cold storage (González-Olivares et al., 2014). Metabolites of aromatic amino acids such as phenylalanine and tryptophan were phenolic and indolic compounds (Dai et al., 2011).

Radical-scavenging activity of kefir made from GM different with $\mathrm{GM}+\mathrm{IN}, \mathrm{GM}+\mathrm{BRE}$ or $\mathrm{GM}+\mathrm{BRE}+\mathrm{IN}$. This activity of kefir containing black rice extract was higher $(p<0.05)$ than other kefir. In addition, radical scavenging activity of goat milk kefir supplemented with inulin $(\mathrm{GM}+\mathrm{IN})$ was higher than goat milk kefir (GM) (Table 4). This results indicates that addition of inulin or black rice extract substitution could increase radical-scavenging activity of goat milk kefir. In a previous study, showed that kefirs demonstrate a more substantial proton-donating ability than do milks and, thus, kefirs can afford protection against proton free radicals since milks fermented by kefir grains demonstrated an enhanced activity as regards scavenging the DPPH radical as compared to unfermented milks (Liu et al., 2005b). One of the antioxidant mechanism is scavenging of proton-radical. DPPH is a substance that has a proton free radical, and this properties can be used to evaluate its proton-radical scavenging activity (Liu et al., 2005b).

Compared to glucose and fructose, inulin has higher scavenging activity due to inulin is more complex soluble molecule or polymer that has many hydroxyl groups. This $\mathrm{OH}$ will capture a proton and an electron to form $\mathrm{H}_{2} \mathrm{O}$ (Peshev et al., 2013). Moreover, it would be reasonable to presume that the number and the position of amino group on pyridine could influence the scavenging property of these inulin derivatives (Hu et al., 2014).

Goat milk kefir containing black rice extract has a higher $(p<0.05)$ radical-scavenging activity than goat milk kefir containing inulin as shown in Table 4 above. This result indicates that antioxidant activity in black rice extract was higher than inulin, because more various an antioxidant compounds in black rice such as phenolic, vitamin $\mathrm{E}$ and phytic acid (Goufo and Trindade (2013). The in vitro study showed that there was correlation between degree of polymerization (DP) and $\cdot \mathrm{OH}$-scavenging activity. While, the number and location of $\mathrm{C}=\mathrm{C}$-type linkages in phenolic compounds was also reported to have great influences on the antioxidant properties (Peshev et al., 2013).

During cold storage at 1-7 d, there was no change in radical-scavenging activity of kefir. This may be due to low activity of microorganism in kefir to produce compound which radical-scavenger during cold storage. Kovačević et al. (2009) stated that storage time less impact in decreasing flavonoid and non-flavonoid compared to processing procedure. Queiroz et al. (2011) also confirmed that activity of scavenging radical DPPH did not affected by storage time. Different with a previous study that percentage of radical scavenging activity of yoghurt added probiotic L. rhamnosus and supplemented green bell pepper juice showed increase during storage at $4^{\circ} \mathrm{C}$ for $7 \mathrm{~d}$ and then decreased (Halah and Mehanna, 2011). The radical scavenging activity of fermented products was influenced by peptides proportion resulted from proteolytic activity of certain strain with a molecular weight of about $4-20 \mathrm{kDa}$ and higher amount of hydrophobic amino acids. Higher the proportion of these peptides, then the higher scavenging activity (Virtanen et al., 2007). Thus, characteristic of strains used in fermented product will determine the development in radical-scavenging activity during storage.

\section{Immunohistochemical of $\beta$-cells}

The effect of kefir prepared with goat milk and black rice extract $(\mathrm{GM}+\mathrm{BRE})$ at various dose on the number

Table 4: The average of total phenolic and DPPH- scavenging activity of kefir groups stored at $4^{\circ} \mathrm{C}$ for 1 and 7 day

\begin{tabular}{|c|c|c|c|c|c|c|}
\hline \multirow{2}{*}{$\begin{array}{l}\text { Kefir } \\
\text { groups }\end{array}$} & \multicolumn{3}{|c|}{ Total phenolic $(\mathrm{mg} / 100 \mathrm{ml})$} & \multicolumn{3}{|c|}{ DPPH (\%) } \\
\hline & $1 \mathrm{~d}$ & $7 d$ & Average & $1 \mathrm{~d}$ & $7 d$ & Average \\
\hline$\overline{\mathrm{GM}}$ & $4.60 \pm 0.75$ & $5.94 \pm 1.03$ & $5.27 \pm 1.09^{\mathrm{a}}$ & $9.98 \pm 1.42$ & $9.98 \pm 6.00$ & $9.98 \pm 3.90^{\mathrm{a}}$ \\
\hline GM+IN & $5.47 \pm 1.09$ & $7.12 \pm 2.60$ & $6.30 \pm 2.00^{\mathrm{a}}$ & $18.24 \pm 2.22$ & $16.63 \pm 1.45$ & $17.44 \pm 1.89^{b}$ \\
\hline $\mathrm{GM}+\mathrm{BRE}$ & $5.53 \pm 1.50$ & $7.40 \pm 2.39$ & $6.47 \pm 2.06^{\mathrm{a}}$ & $23.01 \pm 3.66$ & $23.18 \pm 0.97$ & $23.09 \pm 2.40^{c}$ \\
\hline GM+BRE+IN & $6.98 \pm 2.14$ & $7.40 \pm 2.31$ & $7.19 \pm 2.01^{\mathrm{a}}$ & $19.41 \pm 2.65$ & $29.11 \pm 2.02$ & $24.26 \pm 5.71^{c}$ \\
\hline Average & $5.64 \pm 1.53^{p}$ & $6.97 \pm 1.95^{q}$ & $6.31 \pm 1.85$ & $17.66 \pm 5.46^{p}$ & $19.73 \pm 7.97^{p}$ & $18.69 \pm 6.79$ \\
\hline
\end{tabular}

Different letters $(a, b, c)$ in the same column or the same row $(p, q)$ indicated significant difference $(p<0.05)$ 
of Langerhans islet and insulin-positive $\beta$-cells shown in Table 5.

In normal rats group (negative control), showed that pancreatic $\beta$ - cells have strong positively insulin on immunohistochemical staining with anti-insulin (Fig. 1.a). In the negative control, showed the highest number of Langerhans islet and insulin-positive $\beta$-cells (Table 5). Furthermore, there was less or no insulin positive $\beta$-cells on immunostaining in untreated diabetic rats (Fig. 1.b) and the number of Langerhans and insulin positive $\beta$-cells were lower $(p<0.05)$ than other groups (Table 5$)$. However, this number was not significant different with kefir groups and glibenclamid group. Goat milk-black rice extract kefir (GM+BRE) treatment $(2.0 \mathrm{ml}$ or $4.0 \mathrm{ml})$ could increase significantly the number of Langerhans and insulin- positive $\beta$-cells similar to glibenclamid and negative control (normal rats) (Table 5).

The rats in this study, were induced by STZ-NA to make them develop type 2 diabetes. STZ only, can cause nuclear defect through activation of cellular damaging pathways by the reactive oxygen species (ROS) such as advanced glycation end products (AGE), polyol pathway, hexosamine pathway and protein kinase (PKC) (Rabbani et al., 2010). In order to partially protect the $\beta$-cells againsts STZ, the rats were injected by NA. Protective effect of NA against STZ- $\beta$ cells-cytotoxicity is to be dependent on the preservation of intracellular NAD pool. On one side NA is a direct precursor of $\mathrm{NAD}$ and on other side is an inhibitor of poly (ADP-ribose) synthetase, an NAD-consuming enzyme activated by STZ-induced DNA injury (Masiello et al., 1998). In addition, $\beta$-cells of rats protected by NA remain well differentiated and at least partially responsive to physiological and/or pharmacological stimuli.

In the present study, the effect of kefir prepared from goat milk and black rice extract could improve $\beta$-cells regeneration similar to antidiabetic agent glibenclamide, due to bioactive compounds in kefir which effect on metabolism in $\beta$-cells. Bioactive compounds from kefir fermentation of goat milk such as bioactive peptide that majority release from casein by microbial protease (Ebner

Table 5: The average number of Langerhans islet and insulin-positive $\beta$-cells

\begin{tabular}{lcc}
\hline Treatment groups & Langerhans & Insulin- positive $\beta$ cells \\
\hline Negative control & $4.18 \pm 0.63^{\mathrm{b}}$ & $69.34 \pm 28.93^{\mathrm{b}}$ \\
Positive control & $1.33 \pm 0.57^{\mathrm{a}}$ & $1.88 \pm 0.40^{\mathrm{a}}$ \\
Kefir GM+BRE $(1.0 \mathrm{ml})$ & $3.28 \pm 1.70^{\mathrm{b}}$ & $29.98 \pm 14.59^{\mathrm{ab}}$ \\
Kefir GM+BRE $(2.0 \mathrm{ml})$ & $3.83 \pm 1.31^{\mathrm{b}}$ & $45.53 \pm 14.59^{\mathrm{b}}$ \\
Kefir GM+BRE $(4.0 \mathrm{ml})$ & $3.98 \pm 0.77^{\mathrm{b}}$ & $45.69 \pm 17.46^{\mathrm{b}}$ \\
Glibenclamide & $3.74 \pm 1.18^{\mathrm{b}}$ & $56.08 \pm 31.11^{\mathrm{b}}$ \\
\hline
\end{tabular}

Different letters $(a, b)$ in the same column indicated significant difference $(p<0.05)$

et al., 2015) exospolysaccharides (EPS) (Medrano et al., 2008). Bioactive peptide and EPS have antioxidant activity an immunomodulatory properties (Madhuri and Prabhakar, 2014; Jones et al., 2014; Ebner et al., 2015). In addition, black rice variety showed higher antioxidant activity than other rice varieties (Goufo and Trindade, 2013). In Table 4, antioxidant activity of kefir prepared from a combination

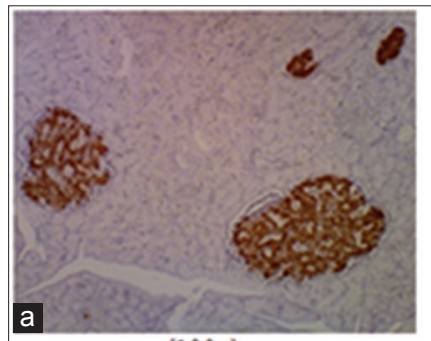

(100x)

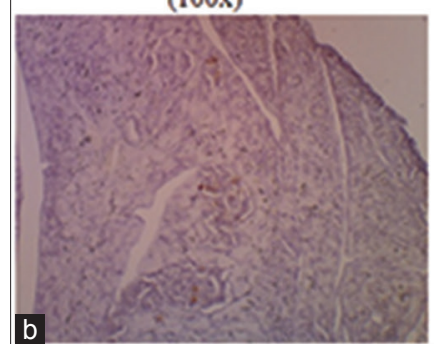

(100x)

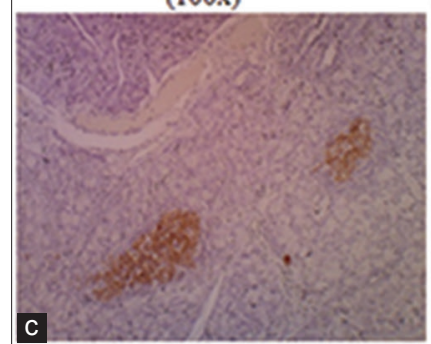

$(100 x)$

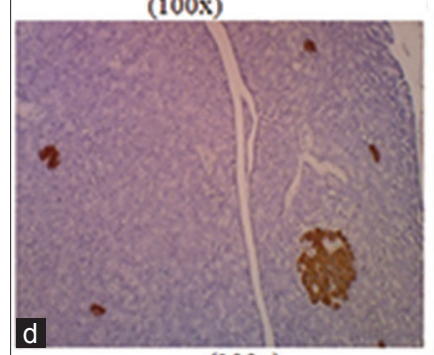

(100x)

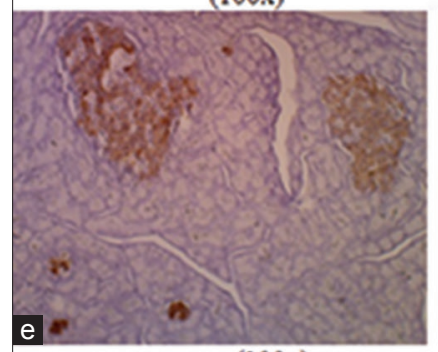

$(100 \mathrm{x})$

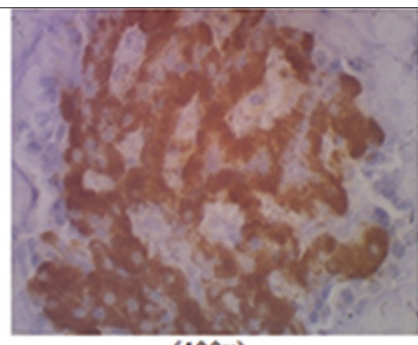

$(400 x)$

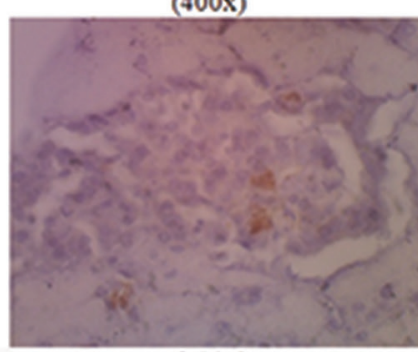

$(400 x)$

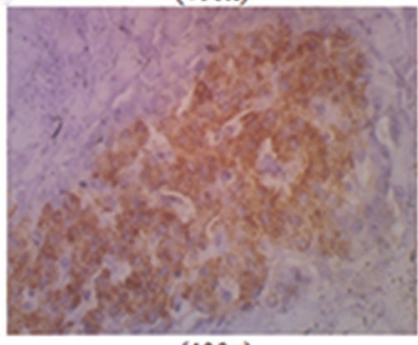

$(400 x)$

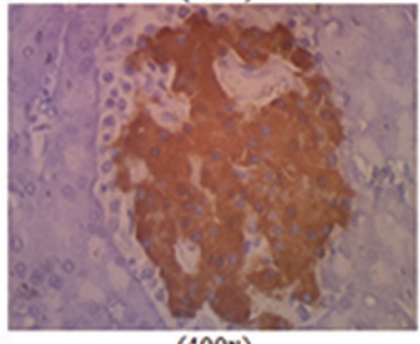

$(400 x)$

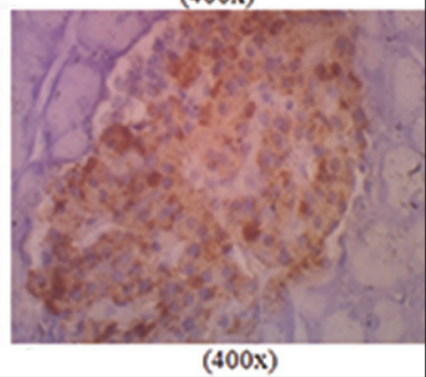

(400x)

Fig 1. a. Negative control group, showing strongly stained by anti-insulin antibody; b. Diabetic group (positive control), showing weak stained and very few the insulin -positive $\beta$-cells; c. Kefir $1.0 \mathrm{ml}$ group, showing moderate staining by anti-insulin; $d$. Kefir $2.0 \mathrm{ml}$ group, strongly stained and protected majority of $\beta$-cells; e. Glibenclamide group. 
of goat milk and black rice extract was higher than goat milk kefir only. The dose of 2.0 or $4.0 \mathrm{ml}$ of kefir have significant effect on the increasing number of Langerhans and $\beta$-cells compared to a dose of $1.0 \mathrm{ml}$ of kefir or untreated diabetics rats. Therefore, for diabetes therapy at least $2.0 \mathrm{ml}$ of kefir dose is required to cause similar effects to that of antidiabetic agents such as glibenclamide.

Glibenclamide has long been used as antidiabetic drugs for type-2 DM due to stimulates insulin secretion by inhibition of ATP -sensitive K+ (KATP) channels in pancreatic tissues. It found that the antioxidant effect of glibenclamide associated with its antimutagenic properties, as well as it has an antiproliferative properties (Rabbani et al., 2010).

\section{CONCLUSIONS}

Substitution of goat milk with black rice extract in kefir fermentation had no adverse effect on the viability of the microorganisms and could decrease of $\mathrm{pH}$. While, the antioxidant activity of kefir could be enhanced by substitution of goat milk with black rice extract and/or inulin addition. During $7 \mathrm{~d}$ of storage at low temperatures, the alcohol and total phenolic contents increased, while the $\mathrm{pH}$ of kefir decreased. The study shows that for the treatment of diabetics at least $2.0 \mathrm{ml}$ dose of kefir combination from goat milk and black rice extract will yield similar effects to that of glibenclamide as an antidiabetic agent.

\section{ACKNOWLEDGEMENTS}

This study was supported by a grant from "Penelitian Unggulan Perguruan Tinggi” 2014, Directorate General of Higher Education, The Ministry of Research, Technology and Higher Education of the Republic of Indonesia.

\section{Author contributions}

Ahmad Hamim Sadewa had a great contribution on the discuss and review paper. Sunarti and Nurliyani had a contribution to overall planning, preparing and performing this research.

\section{REFERENCES}

Adriana, P. and C. Socaciu. 2008. Probiotic activity of mixed cultures of kefir's lactobacilli and non-lactose fermenting yeasts. Bull. UASVM Agric. 65: 329-334.

Akbarzadeh, A., D. Norouzian, M. R. Mehrabi, S. Jamshidi, A. Farhangi, A. Verdi, S. M. Mofidian and B. L. Rad. 2007. Induction of diabetes by streptozotocin in rats. Indian J. Clin. Biochem. 22: $60-64$.

Alyaqoubi, S., A. Abdullah, M. Samudi, N. Abdullah, Z. R. Addai and M. Al-Ghazali. 2014. Effect of different factors on goat milk antioxidant activity. Int. J. ChemTech. Res. 6: 3091-3196.
AOAC. (1995). Official Methods of Analysis of the Association of Official Analytical Chemistry. 16th ed. AOAC International, Washington, USA.

Bergmann, R. S., M. A. Pereira., S. M. Veiga., J. M. Schneedorf., N. M. Oliveira and J. E. Fiorini. 2010. Microbial profile of a kefir sample preparations: Grains in natura and lyophilized and fermented suspension. Ciênc. Tecnol. Aliment. 30: 1022-1026.

Chen, M. J., J. R. Liu., J. F. Sheu., C. W. Lin and C. L. Chuang. 2006. Study on skin care properties of milk kefir whey. Asian Australas. J. Anim. Sci. 19: 905-908.

Chu,Y. F., J. Sun., X. Wu and R. H. Liu. 2002. Antioxidant and antiproliferative activities of common vegetables. J. Agric. Food Chem. 50: 6910-6916.

Cruz-Guerrero, A. E., J. L. Olvera., M. García-Garibay and L. Gómez-Ruiz. 2006. Inulinase-hyperproducing strains of Kluyveromyces sp. isolated from aguamiel (Agave sap) and pulque. World J. Microb. Biot. 22: 115-117.

Dai, Z. L., G. Wu and W. Y. Zhu. 2011. Amino acid metabolism in intestinal bacteria: Links between gut ecology and host health. Front. Biosci. 16: 1768-1786.

Ebner, J., A. A. Arslan., M. Fedorova., R. Hoffmann., A. Küçükçetin and M. Pischetsrieder. 2015. Peptide profiling of bovine kefir reveals 236 unique peptides released from caseins during its production by starter culture or kefir grains. J. Proteomics. 18: 41-57.

Eissa, E. A., A. E. Yagoub., E. E. Babiker and I. A. Ahmed. 2011. Physicochemical, microbiological and sensory characteristics of yoghurt produced from camel milk during storage. Electron. J. Environ. Agric. Food Chem. 10: 2305-2313.

Fakruddin, M., M. A. Islam., M. A. Quayum., M. M. Ahmed and N. Chowdhury. 2013. Characterization of stress tolerant high potential ethanol producing yeast from agro-industrial waste. Am. J. BioSci. 1: 24-34.

Garrote, G. L., A. G. Abraham and L. De Antoni. 2000. Inhibitory power of kefir: The role of organic acids. J. Food Prot. 63: 364-369.

González-Olivares, L. G., J. Añorve-Morga., A. Castañeda-Ovando., E. Contreras-López and J. Jaimez-Ordaz. 2014. Peptide separation of commercial fermented milk during refrigerated storage. Food Sci. Technol. 34: 674-679.

Goufo, P. and H. Trindade. 2014. Rice antioxidants: phenolic acids, flavonoids, anthocyanins, proanthocyanidins, tocopherols, tocotrienols, $y$-oryzanol, and phytic acid. Food Sci. Nutr. 2: 75-104.

Guzel-Seydim, Z., T. K. Tas., B. Ertekin-Filiz and A. C. Seydim. 2011. Effect of different growth conditions on biomass increase in kefir grains. J. Dairy Sci. 94: 1239-1242.

Halah, M. F. and N. S. Mehanna. 2011. Use of natural plant antioxidant and probiotic in the production of novel yogurt. J. Evol. Biol. Res. 3: $12-18$

Hashim, I. B., A. H. Khalil and H. S. Afifi. 2009. Quality characteristics and consumer acceptance of yogurt fortified with date fiber. J. Dairy Sci. 92: 5403-5407.

Hwanhlem, N., A. Buradaleng., S. Wattanachant., S. Benjakul., A. Tani and S. Maneerat. 2011. Isolation and screening of lactic acid bacteria from Thai traditional fermented fish (Plasom) and production of Plasom from selected strains. Food Control. 22: 401-407.

Hernandez-Marin, E. and A. Martínez. 2012. Carbohydrates and their free radical scavenging capability: A theoretical study. J. Phys. Chem. B. 116: 9668-9675.

Hu, Y., J. Zhang., C. Yu., Q. Li., F. Dong., G. Wang and Z. Guo. 2014. Synthesis, characterization, and antioxidant properties of novel inulinderivatives with amino-pyridine group. Int. J. Biol. Macromol. 70: 44-49. 
Hutkins, R.W. and N.L. Nannen. 1993. pH Homeostasis in lactic acid bacterial. J. Dairy Sci. 76: 2354-2365.

Jones, S., M. L. Paynich and K. L. Knight. 2014. Exopolysaccharides: Sweet success with probiotic therapeutics. Inflamm. Cell Signal. 1: $1-8$.

Judiono, Djokomoeljanto. and S. Hadisaputro. 2011. Effects of oral clear kefir probiotics on glycemic status, lipid peroxidation, antioxidative properties of streptozotocin induced hyperglycemia wistar rats. Gizi Indones. 34: 1-6.

Kanter, M., O. Coskun., A. Korkmaz and S. Oter. 2004. Effects of Nigella sativa on oxidative stress and -cell damage in streptozotocininduced diabetic rats. Anat. Rec. A. 279A: 685-691.

Kelly, G. 2008. Inulin-type prebiotics - A review: Part 1. Altern. Med. Rev. 13: 315-329.

Kovačević, D. B., B. Levaj and V. Dragović -Uzelac. 2009. Free radical scavenging activity and phenolic content in strawberry fruit and jam. Agric. Conspec. Sci. 74: 155-159.

Kris-Etherton, P. M., Hecker, K. D., Bonanome, A., Coval, S. M., Binkoski, A. E., Hilpert, K. F., Griel, A. E and T. D. Etherton. 2002. Bioactive compounds in foods: Their role in the prevention of cardiovascular disease and cancer. Am. J. Med. 113: 71S-88S.

Lattanzio, V., V. M. Lattanzio and A. Cardinali. 2006. Phenolics in the resistance mechanisms of plants against fungal pathogens and insects. In: Phytochemistry: Advances in Research. Research Signpost, India. Pp. 23-67.

Leite, A. M., D. C. Leite., E. M. Del Aguila., T.S. Alvares., R. S. Peixoto., M. A. Miguel., J. T. Silv, and V.M. Paschoalin. 2013. Microbiological and chemical characteristics of Brazilian kefir during fermentation and storage processes. J. Dairy Sci. 96: 4149-4159.

Liu, J. R., Y. Y. Lin., M. J Chen., L. J. Chen and C. W. Lin. 2005a. Antioxidative activities of kefir. Asian Australas. J. Anim. Sci. 18: 567-573.

Liu, J. R., M. J. Chen and C. W. Lin. 2005b. Antimutagenic and antioxidant properties of milk-kefir and soymilk-kefir. J. Agric. Food Chem. 53: 2467-2474.

MacLeod, L. D. 1949. Determination of alcohol by microdiffusion. J. Biol. Chem. 181:323-331.

Madhuri, K. V. and K. V. Prabhakar. 2014. Microbial exopolysaccharides: Biosynthesis and potential applications. Orient. J. Chem. 30: 1401-1410.

Medrano, M., P. F. Pérez, and A. G. Abraham. 2008. Kefiran antagonizes cytopathic effects of Bacillus cereus extracellular factors. Int J Food Microbiol. 122: 1-7.

Masiello, P., C. Broca., R. Gross., M. Roye., M. Manteghetti., D. Hillaire-Buys., M. Novelli and G. Ribes. 1998. Experimental NIDDM development of a new model in adult rats administered streptozotocin and nicotinamide. Diabetes. 47: 224-229.

Modzelewska-Kapitula, M., L. Klebukowska and K. Kornacki. 2007. Influence of inulin and potentially probiotic Lactobacillus plantarum strain on microbiological quality and sensory properties of soft cheese. Pol. J. Food Nutr. Sci. 57: 143-146.

Montanuci, F. D., T. C. Pimentel., S. Garcia and S. H. Prudencio. 2012. Effect of starter culture and inulin addition on microbial viability, texture, and chemical characteristics of whole or skim milk kefir. Ciênc. Tecnol. Aliment. 32: 850-861.

Mundt, J. O., W. F. Graham and I. E. Mccarty. 1967. Spherical lactic acid-producing bacteria ofsouthern-grown raw and processed vegetables. J. Appl. Microbiol. 15: 1303-1308.

Oliveira, R. P., P. Perego., M. N. Oliveira and A. Converti. 2012. Effect of inulin on the growth and metabolism of a probiotic strain of Lactobacillus rhamnosus in co-culture with Streptococcus thermophilus. LWT Food Sci. Technol. 47: 358-363.

Oner, Z., A.G. Karahan and M.L. Cakmakci. 2010. Effects different milk types and starter cultures on kefir. GIDA. 35: 177-182.

Otles, S. and O. Cagindi. 2003. Kefir: A probiotic dairy-composition, nutritional and therapeutic aspects. Pak. J. Nutr. 2: 54-59.

Peshev, D., R. Vergauwen., A. Moglia., E. Hideg and W. van den Ende. 2013. Towards understanding vacuolar antioxidant mechanisms: a role for fructans?. J. Exp. Bot. 64: 1025-1038.

Queiroz, C., M. L. Lopes., E. Fialho and V. L. Valente-Mesquita. 2011. Changes in bioactive compounds and antioxidant capacity of fresh-cut cashew apple. Food Res. Int. 44: 1459-1462.

Rabbani, S. I., K. Devi and S. Khanam. 2010. Protective role of glibenclamide against nicotinamidestreptozotocin induced nuclear damage in diabetic Wistar rats. J. Pharmacol Pharmacother. 1: 18-23.

Reeves, P. G., F. H. Neilsen and G. C. Fahey, JR. 1993. AIN-93 Purified Diets for Laboratory Rodents: Final Report of the American Institute of Nutrition Ad Hoc Writing Committee on the Formulation of the AIN-76A Rodent Diet. J. Nutr. 123: 19391951.

Roostita, L. B., G. H. Fleet., S. P.Wendry., Z. M. Apon and L. U. Gemilang. 2011. Determination of yeasts antimicrobial activity in milk and meat products. Adv. J. Food Sci. Technol. 3: $442-445$.

Shah, N. P. and R. R. Ravula. 2000. Influence of water activity on fermentation, organic acids production and viability of yogurt and probiotic bacteria. Aust. J. Dairy Technol. 55:127-131.

Sheela T. and R. S. Suganya. 2012. Studies on synbiotic barley grain extract against some human pathogens. Int. Res J Pharm. 3: 126-129.

Shori, A. B. 2013. Antioxidant activity and viability of lactic acid bacteria in soybean-yogurt made from cow and camel milk. J. Taibah. Univ. Sci. 7: 202-208.

Sirirat, D. and P. Jelena. 2010. Bacterial inhibition and antioxidant activity of kefir produced from Thai jasmine rice milk. Biotechnology. 9: 332-337.

Sompong, R., S. Siebenhandl-Ehn., G. Linsberger-Martin and E. Berghofer. 2011. Physicochemical and antioxidative properties of red and black rice varieties from Thailand, China and Sri Lanka. Food Chem. 124: 132-140.

SPSS 12.0. (2003). Brief Guide. SPSS Inc., 233 South Wacker Drive $11^{\text {th }}$ Floor Chicago, USA.

Tas, T. K., E. Ilay and A. Öker. 2014. Determination of some quality criteria of the kefir produced with molasses and plum. Turk. J. Agric. Food Sci. Technol. 2: 86-91.

Trachoo, N., C. Boudreaux., A. Moongngarm., S. Samappito and R. Gaensakoo. 2006. Effect of germinated rough rice media on growth of selected probiotic bacteria. Pak. J. Biol. Sci. 9: 26572661.

Uray, A. D. 2009. The profile of beta- Cells on the islets of langerhans pancreatic tissue of diabetes mellitus rats treated by virgin coconut oil (VCO). Thesis. Faculty of Veterinary Medicine, Bogor Agricultural University.

Virtanen, T., A. Pihlanto., S. Akkanen and H. Korhonen. 2007 Development of antioxidant activity in milk whey during fermentation with lactic acid bacteria. J. Appl. Microbiol. 102: $106-115$.

Witthuhn, R. C., T. Schoeman and T. J. Britz. 2005. Characterisation of the microbial population at different stages of Kefir production and Kefir grain mass cultivation. Int. Dairy J. 15: 383-389. 